\title{
REAL TIME MARKETING IMPLEMENTATIONS: EXAMPLE OF KADIKÖY MUNICIPALITY
}

\author{
Deniz AKÇAY \\ İstanbul Gelişim University, İstanbul \\ dakcay@gelisim.edu.tr \\ İpek OKKAY \\ İstanbul Gelişim University, İstanbul \\ iokkay@gelisim.edu.tr
}

\begin{abstract}
With the development of the Internet and the emergence of two way communication along with it, the issue of marketing has gained even a greater importance for organizations. With the Internet, various marketing models such as viral marketing, content marketing, avatar marketing, interactive marketing and real time marketing became necessary. In particular, when social media is used concurrently with the agenda in an accurate manner, it presents organizations with a great opportunity to promote themselves. The purpose of the study is to find the answer to the question whether Real Time Marketing applications increase the visibility of organizations or not. Accordingly, an in-depth interview has been conducted with the officials of the social media department of Kadiköy municipality. The reason why Kadiköy municipality has been included in the sample is that it has become news story in the media with about 10.000 re-tweets to its \#backtotefuture content it has posted on Twitter on 21 October, 2015.
\end{abstract}

Keywords: Social media, real time marketing, marketing

\section{GERÇEK ZAMANLI PAZARLAMA UYGULAMALARI: KADIKÖY BELEDIYYESİ ÖRNEĞİ}

\section{ÖZ}

İnternetin gelişmesi ve beraberinde çift yönlü iletişimin de ortaya çıkışıyla pazarlama konusu kurumlar için çok daha önemli bir hal almıştır. İnternetle birlikte pazarlama konusuda viral pazarlama, içerik pazarlaması,avatar pazarlama, interaktif pazarlama ve gerçek zamanlı pazarlama gibi çeşitli pazarlama modellerine ihtiyaç duyulmuştur. Özellikle sosyal medya gündemle eş zamanlı olarak doğru kullanıldığında kurumlara kendilerini tanıtmaları açısından çok büyük firsat sunmaktadır. Çalışmanın amacı, Real Time Marketing uygulamalarının kurumların görünürlüğünü artırıp artırmadığını sorusuna yanıt bulmaktır. Buna göre kadıköy belediyesinin sosyal medya departmanı yetkilileriyle derinlemesine mülakat yapılmıştır. Çalışmada kadıköy belediyesinin örnekleme dahil edilmesinin nedeni ise 21 Ekim 2015 tarihinde twitter üzerinden yayınladığı \#backtotefuture içeriğiyle 10.000 civarında re-tweet alarak basinda haber olmasidır.

Anahtar Kelimeler: Sosyal medya, gerçek zamanl pazarlama, pazarlama

\section{INTRODUCTION}

When we take a brief look at the history of marketing, it is seen that marketing has developed as the options of mass communication devices became wide-spread and that competition in mass production and consumption which have been shaped in the beginning of 20th century (production era) has begun to increase. In this era, it is seen that very little promotions have been done for goods and the idea that whatever I produce and I sell has been dominant. In the era following this, the brands of the great competitive environment impose the prioritization of individual sales which are supported by 
researches, promotions and advertisement. With this era which is defined as sales orientation, the sudden increase in competition in the 1950's and the emergence of individual customers ethics, the complex marketing orientation has begun to be adopted by many firms and firms began to focus on branding and positioning of goods and gave more consideration to customers' needs and expectations (Cornesillen, 2004:37-38). In the 1960's, it is seen that the activities in the area of marketing are under the influence of marketing mix and marketing management (Alabay, 2010:2). In the 1970's, it is seen that the interest are of marketing became non-profit organizations and social marketing. In the 1980's, computers began to be used in business life. Starting with the 1980's and the 1990's, computers became a part of the business and daily life of individuals. In the 2000's, with the use of the Internet for personal purposes, establishments' using the Internet as a part of marketing and recording customer data. Kiang and et.al argues that "marketing activity occurs through three types of channels: distribution, transaction, and communication channels" (Kiang and et.al, 1999: 384). The developing technologies, the creation of new marketing concepts and people's being able to share their thoughts through social media has pushed firms to be real time. Today, social media is a significant platform of entertainment and knowledge acquisition. In addition, social media is very effective in transmitting the messages of organizations to the target masses. The most striking example of this is seen in the real time use of social media by organizations to promote their products, services and special campaigns. This simultaneous sharing has brought the real time marketing efforts along with it as well.

\section{REAL TIME MARKETING}

Nguyen (2015) states that real time marketing involves the digital world, the production of infrastructure, organization and communication and expresses that social media hold a key position in brands' being included in the conversations about themselves (Nguyen, 2015:11). Real time marketing becomes more advantageous for the promotion of goods in line with the rapidly changing trends and tendencies. One of the greatest viral effects created by Real Time marketing is that it can reach a large public with a much lesser budget. Real Time marketing depends not only on reducing the advertisement costs through the use of events which naturally take place within the framework of opportunities provided by technology as a marketing tool, but also on the willingness of the person doing the marketing to manage customers relations for the center. Oliver and et al. argues that Realtime Marketing calls for goods and services that are not only customizable to the individual consumer, but also inherently capable of adapting themselves over time (Oliver and et.al, 1998:29). 'Branding in real-time creates a center of gravity, a locus of intention and action that draws in fans, advocates, partners, and power' (Macy and Thompson, 2011:66).

In order for Real Time marketing to be successful, firstly organizations need to listen to their customers. At this point, Macy and Thomson suggest certain strategies. Some of these are as follows:

*Listening

*Responding

* Staying nimble

*Engaging in reputation management

*Thinking counter intuitively (Macy and Thompson, 2011:63)

Listening is one of the most important aspects in terms of people making decisions, taking action, being oriented and being guided. Listening which is extremely important for people has become quite important for organizations as well today with the rapid spread of the Internet. In order for organizations to be able to perform effective listening, they need to make use of information communication technologies. Today, when listening is performed through technological ways, that is in the web environment, it is possible to report the conversations related to you organization. As organizations can find out about the views related to them free of charge through Google analytics, they can do the same through getting support of social media agents in return for a fee. "They can send the alerts to you in real time as they find the mentions or gather them up and send a report or e-mail daily or weekly" (Klososky, 2011:87). Handley states that it is quite important for organizations to have a central place in order to coordinate their listening activities in terms of success and that RSS is a web page notifies which allows the newly added content easily to be followed (Handley and Chapman, 2012:174) Handley expresses that there are free web page notifier such as Google reader

Submit Date: 01.10.2016, Acceptance Date: 21.12.2016, DOI NO: 10.7456/10701100/009

Copyright $(\odot$ The Turkish Online Journal of Design, Art and Communication 
and Google alerts which give the same service as RSS and that Twitter's search function over search.twitter.com also allows to see the whole usage of a word or sentence in question on Twitter in the last two weeks (Handley and Chapman, 2012: 173-175). The content of these sites and our following the content they provide us helps firms to see their strong and weak areas, opportunities and threats; in others words, to do SWOT analysis According to Reece (2010), some of the key aspects we need to give importance to while following these contents are as follows (Reece, 2010:100):

- Identifying rivals

- Following what is said about the firm and its key administrators

- Following the tendencies/trends in one's own sector

- Following the goods and services in one's own sector

- Receiving feedback from the people in your network

- Exchanging ideas with the other people in your network

- Discovering new sources

- In this manner, organizations are able to perform more successful real time marketing activities.

It is extremely important to listen to the views of customers and act accordingly. What is important is to communicate with the followers and answer their questions. While doing this in the Internet environment, it is necessary to be speedy and solution centered. While certain organizations use in particular the automatic reply method when answering their customers' questions, some others reply one-to-one. Other than these methods, not replying creates a negative image for firms. Another point to while answering questions on social media is to consider the reputation of the firm.

Corporate reputation is defined as the perceptions of the target group inside and outside the firm about the firm (Ural, 2012: 85). Reputation becomes an abstract entity which shows how a firm is perceived by the employees and the customers (Karaköse, 2007:2). Kadıbesegil defines reputation as the reward of being a firm which is appreciated by the public (Kadıbessegil, 2012: 59). To be able to be appreciated by the public, it is important to meet the demands of customers in real time. In this respect, in order to be able to preserve corporate reputation, the posts need to be followed in real time as well.

In terms of reputation, firms make the promise of measuring, evaluating, clarifying an enormous amount of information about the image or reputation of the firm coming from various sources and transmitting these to the firm in real time (Er, 2008:151). Informing the firm which has been done in the past through traditional methods can be performed today through the Internet and in particular social media. The management of corporate reputation has been becoming increasingly more difficult and important. The following are some methods of preserving online reputation (Dennis, 2013: 1819):

- Through the proactive reputation method, developing related positive online content has been gaining importance. Today, as many firms actively use their social media profiles, having a powerful site can play an effective role for firms in reducing the effect of negative online messages.

- It has become important to reply to online criticisms in real time. To achieve this, professional comment sites such as Yelp, Angie's List and Healthgrades can be used. These sites prevent subjective comments about businesses or professionals and turn them into positive ones.

- It is important that the firm's social media policy's online communication activities are carried out in a respectful, candid, cultural manner or in line with the values of the firm towards both its employees within the firm and its customers outside the firm. It is also important for the reputation of the firm that the employees adopt the same policy and if there is need, for them be trained in terms of this issue and the firm to share content accordingly.

- When difficult conditions arise due to the erroneous online communication applications giving rise to financial loss due to slander, it becomes necessary to consult a legal consultant. In cases of slander and similar situations, as filing a lawsuit can prevent the firm to receive a greater damage, it is also important in terms of helping to gain the reputation back and compensating for the loss of revenue. 
In the social media environment, if we take into consideration that people share their positive views besides negative views, and even insults about brands, the "engaging in reputation management" point listed among the points above is highly important in real time management.

Today, since negative views about firms spread on the Internet, this viral effect pushes firms to think fast. If the problems are not immediately supported, corporate reputation can get damaged. We can also use data we obtain from the views of the target group in increasing reputation. In real time, intuitive thinking should also be given importance to besides these data. What is important here is to recognize the popular issues which make up the agenda and to use these accurately. In this stage, although grabbing the interest of people carries importance certain tactics need to be developed for this purpose.

According to Forbes, some of the tactics which need to be employed to grab attention while doing real time marketing on social media are as follows:

Having an effective follower base: This has become necessary today. If there is no such base, we cannot expect our posts to create a viral effect.

Not worrying about being the first: Following the trend and being the first in something has also become important. Sharing posts on Facebook and Twitter has become important. Communicating with the target groups has become important. In real time marketing, taking action knowing about the interest area of your target group is important.

Being careful: Since real time marketing requires rapidly and accurately taking decisions, being careful leads to success (Olenski S, 2015, http://www.forbes.com)

Along with the aspects mentioned above, seasonality, holidays and special days, days, hours, natural or interesting events etc. Carry a guiding quality for firms while creating content in Real Time Marketing. Güldaş states that firms in the content they create need to take their customers as the basis, design their content by identifying on which Digital Media they are going to share them and knowing what the Dynamics of these media and need to pay attention to the fact that there is a strategic distribution in terms of time as well (http://www.emreguldas.com/?s=Real+time+marketing). After making sure that these steps are accurately applied, it is important that the firm follows how much mention the content created in real time gets mention to be able to measure the success of the firm. In this respect, Klososky (2011) explains the points which need to be considered to be able to actively use real time marketing:

- How much mention you receive in Tweets, Blogs, Facebook and similar sites to Facebook; in short, in social media

- Increase in the number of mentions in comparison to the previous month

- The quality of the content the organization shares

- With the help of the quality of content shared by the organization, the messages exceeding the number of people who follow the firm and reaching everyone

- The proportion of negative messages to positive messages

- Third-party ratings from relevancy measurement sites (Klososky, 2011: 92)

As mentioned above, Social Networks have facilitated collection of data. With the entering of easily carried technologies such as smart phones in our lives and being able to connect to the Internet through technologies such as $3 \mathrm{G}$ and $4 \mathrm{G}$, the chance of collecting real time data has increased. By means of social networks, customer problems can immediately be solved today and this allows giving immediate supports to customers. As organizations realize these problems in Real Time Marketing and solve them, they are also able to shape their products in accordance with the tendencies of customers. The yare able to use social media sites to both analyze customer profiles and to carry out real time marketing campaigns. To be able to carry out all of these in an accurate manner by organizations and achieve success, the right solution will be to give simultaneous customer services and carry the characteristic of call centers to the Internet. Below are some examples as to how effective real time marketing is: 
Google's Google smart box joke dated 1 April, 2016. Google in this April Fool's Day joke announced that it would be giving a new service to its users by equipping its classic mailbox with technology. Google had so realistically prepared this joke that, it has convinced its users that it would be a real service. To give a few examples to show why the users believed it, these could be mentioned: The filtering of unwanted real mails in Google's new smart mailbox; grouping of mails among themselves in a folder and carrying your mailbox wherever you want (http://www.theverge.com/2015/4/1/8327379/april-fools-roundup). The users for these reasons totally believed this Google product promotion.

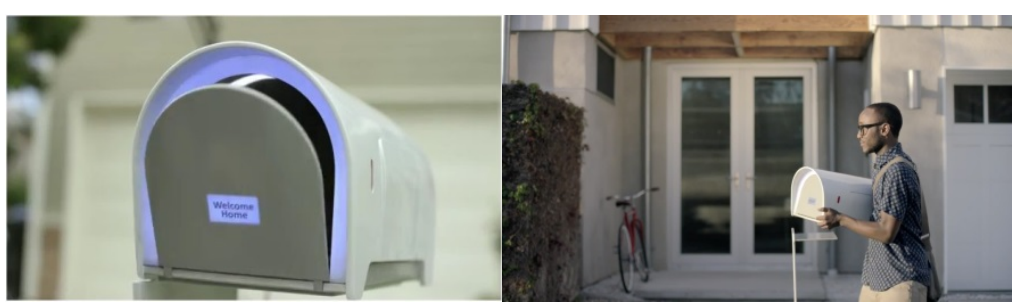

Image 1. Google smart box joke

The firm Pegasus actively makes use of real time marketing. For instance, it has been able to grab the interest of its customers with real time content such as "Your Fortune Says You are Going to Travel Of Course, If You Buy Your Ticket for the Most Suitable prices from Pegasus" and "Check Your Points, Better Yet Fly with Pegasus and Do not Leave it Alone in the Deplacement" in Google Adwords. Similarly, by creating its real time marketing campaign "atlayıpgitsem" ("let me jump on the plane and fly") during the Galatasaray-Chelsea match in parallel with "Forget about the Goals of the Match, Jump on Pegasus, Go to London and Do not Leave your Team Alone in the Deplacement" texts and supported it and thus has been able to achieve $10 \%$ additional traffic to its site (http://sosyalmedya.co/gercek-zamanli-pazarlama-ornekleri/).

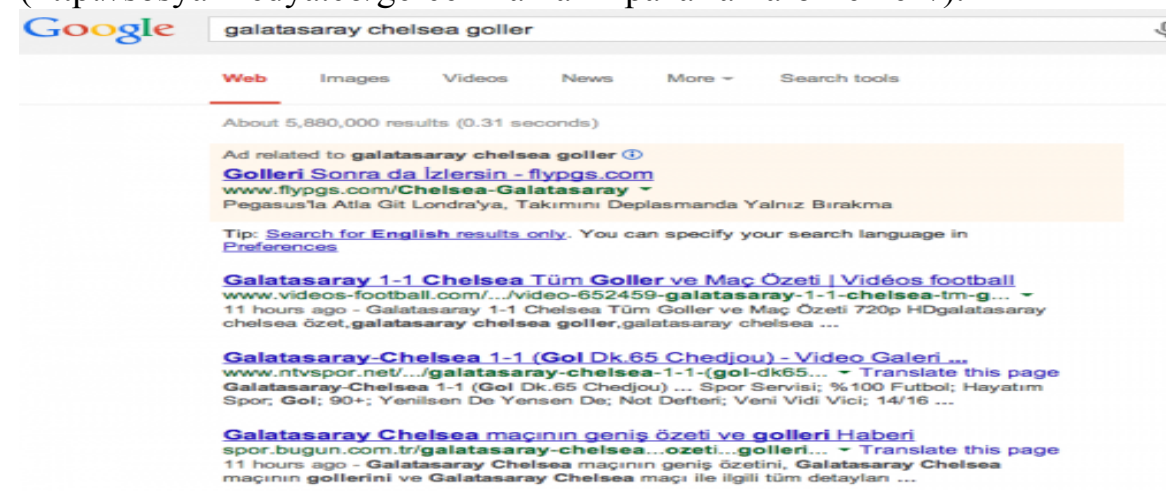

Image 2. Galatasaray Chelsea goller

Another example is brands such as Turkcell which shared a photograph titled "I Love Pluton" with a reference to the "heart" shape which appeared on the planet on NASA's Twitter account when NASA shared the first image of its flight to Pluton on its Instagram account and made use of real time marketing using this occasion (http://fikrimesai.com/markalarin-pluton-ile-ilgili-gercek-zamanlipazarlama-cabalari/).

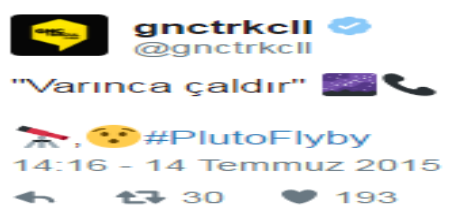

Image 3. I Love Pluton

As these kinds of activities increase the visibility of firms, they can also develop the reputation of the firm by reaching millions of people as they create a viral effect when they are successful. What is 
important here is to know the target group well. Since real time marketing requires taking fast decisions, the firm can be affected negatively when it is not carried out with care. As an example, KFC's real time marketing activity can be given.

Although the advertisement content of KFC's Australia campaign to appear on Twitter consisting of a man covered in pixels and a woman sitting next to him was supposed to create a sexy perception, it has been perceived as obscene. The writing in the content text "Warning: Disturbing content! Something hot and spicy is coming!" reinforced this perception, received negative reactions from the public and it was deleted in the end by the firm. In the time until it was deleted, it was retweeted 1300 times and as a result of being marked as negative by a high number of users, the firm had to post an apology message. In this message, KFC stated "We did not wish to hurt anyone, we are truly sorry. We have removed our post since it caused a wrong perception" (http://sosyalmedya.co/kfc-paylastigimustehcen-tweetini-1-saat-icinde-sildi-ama-sosyal-medyanin-gundemi-oldu/)

In order not to come face to face with such a situation, the firms need to be careful what they are posting and it is highly important that they know the target groups very well. Real time marketing activities which ignore this can cause negative reactions and give damage to the firm's reputation.

\section{METHOD OF THE STUDY}

In the study, it has been attempted to present how important the issue of real time marketing is in relation to firms' reaching larger masses through the interview made with Kadıköy Municipality's social media officials on 02.04.2016. The main reason why Kadıköy Municipality has been included in the study is that the municipality's \#backtothefuture tweet has been retweeted 10.000 times and has greatly been given place in the pres. The tweet in question has been given place to in Sözcü newspaper's article titled Back to the Future in Social Media with Fun Caps dated 21 October 2015, with the content "We are looking for the person who has stolen the vest of our Kadıköy Municipality cleaner who claims he has come from the past on 07:28 this morning \#backtothefuture" as a funny news which came from the social media account of the municipality. In the interviews, questions in particular as to how the municipality carries out real time marketing activities, how the approval process takes place in relation to the subject, whether there are projects initiated by taking the comments made about Kadıköy municipality and how they preserve their brand fame although the yare a state institution.

Kadıköy municipality's social media coordinator Ulaş Yılmaz has stated in the interview that they actively use social media and that in social media environments such as Facebook, Instagram, YouTube, Flicker, Foursquare, Wayn and Vimeo, they exist with a single account. Yilmaz has expressed that the municipality's social media users of over 50 years of age are close to 150.000 and the younger population is about 1.000 .000 and that as a municipality they have to address both groups. However, Y1lmaz has also stated that they have witnessed that the channels change according to the age group and that as there is a much older generation on Facebook, there is a younger generation on Twitter and the youngest population is on Instagram. Ulaş has stated that the most checked in place on Foursquare is Kadıköy. We are able to reach a much wider target group through Real Time Marketing.

Ulaş has stated that they are able to reach a much wider target group over social media and in particular through real time marketing strategy and as an example, has stated that the number of readers they can reach when they are in the news in a national newspaper is limited with that newspaper. For instance, if the number of readers is 350.000 people, the 2.000 .000 social media followers of Kadıköy municipality display the difference clearly. Ulaş has stated that they are given place to more in pres when there is very special news about the municipality or when the lord mayor has an announcement, whereas they are in interaction with each small target group on social media.

What is important in service marketing is that people are able to reach organizations.

In the rest of his interview, Ulas has expressed the importance of people reaching organizations through social media as follows: 
"When you exist in all places in social media, people can write to us whenever they like and get information. Therefore, a piece of information about us given in a national newspaper is not really beneficial. In the past, newspapers had complaint and İstanbul pages; when there was a problem with a pavement, a problem to do with the garbage or parking demand, people would write there. However, the newspapers do not have such columns anymore. After that, the places people could reach decreased in number in national pres. Due to all of these reasons, social media is a very easy place for them to reach us. Right now, our Instagram account is our social media channel which gets the most interaction and has the most followers. Through our Instagram page, people can directly write about their complaints. In the national press, in order for people to solve their problems, that is problems related to the municipality, they firstly need to have a new article written by the newspaper and this is not easy to do. However, they are able to reach us easily through the social media and Express their problems.

\section{Real Time Marketing and Brand Reputation}

Ulaş has stated that they do not carry out real time marketing in a planned manner and that a reputation loss can be experienced when a wrong content is shared at the wrong time. Yilmaz has expressed how they prevent reputation loss in the Real Time Marketing activities as follows:

"Kadıköy municipality has got a style and it is a recognized style now. Kadıköy municipality uses its social media accounts as a person and uses a candid language. Therefore, a phenomenon called Kadıköy municipality was created. As for complaint management system, we have used a more humane, sincere and warm language. We have used a serious but sincere language which puts the coldness of state organizations away. The general policy of the municipality is not so and the language used in social media is a candid one. RTM?? In fact we do this every time. There are no upper level institutions we consult, because we always know what to use and when. Firstly, we know Kadıköy, its residents and our municipality very well. Therefore, we are able to decide what kind of content to post or not by ourselves. For instance, TUBİTAK announces a piece of news: "Kurbağalı creek water is drinkable." We say, it if can be drinkable, then we are sending it to you to make tea. In other words, we are saying that Kurbağalı creek is a major problem and we have taken it as a problem, but TUBITAK's report cannot be taken seriously. Or that the cleaning of the place belongs to İstanbul Metropolitan Municipality. Accordingly, we take a photograph of the creek and post it as saying "Is this Neptune's surface? Or is it Kurbağalı Creek?" with a reference to IMM. If there had been a different kind of bureaucracy, Real Time Marketing would not be possible. We do not work with any agency either."

Yilmaz has stated about Real Time Marketing that their main problem as different from the other brands is the fact that they are a state institution. He has also expressed that they had thought about the \#backtothefuture (10.000 retweets) and \#starwars (4000 retweets) much before.

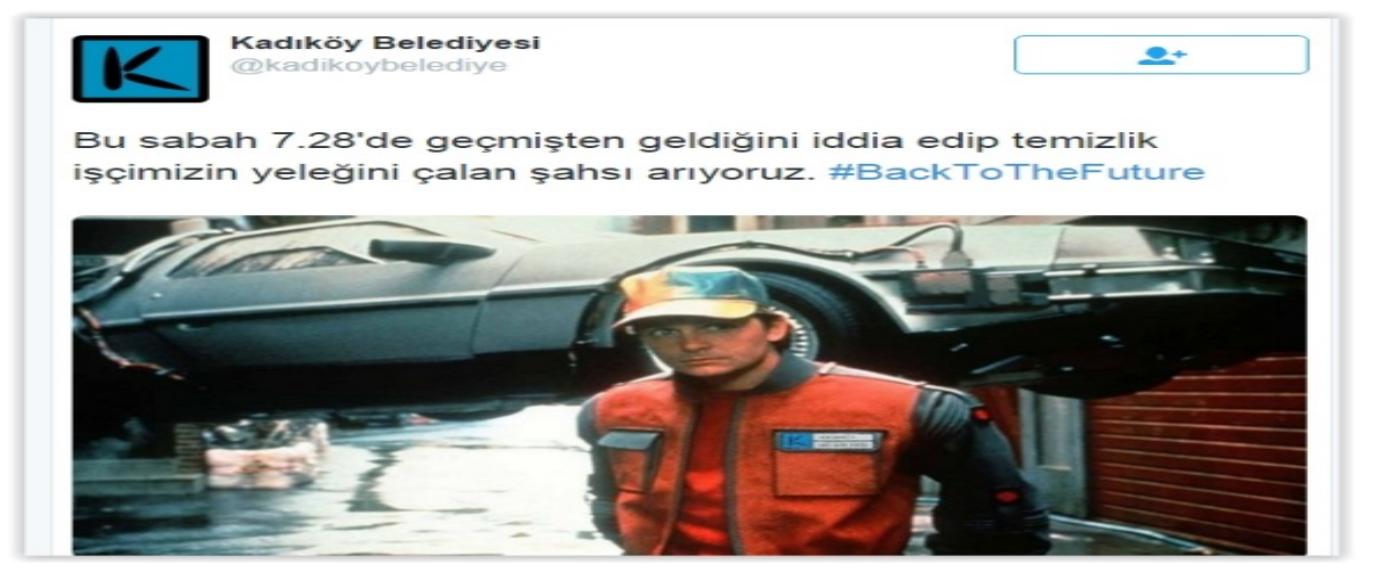

Image 4. \#backtothefuture 


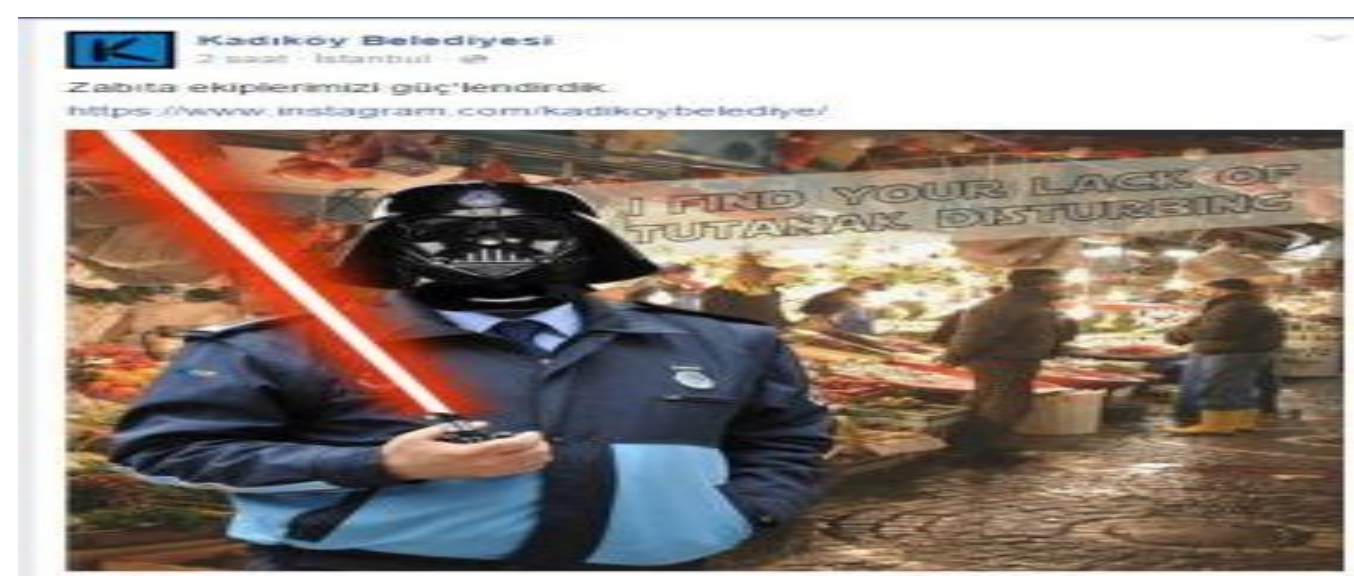

Image 5. \#starwars

We use a humorous and elite language on social media

Yllmaz has stated that people were not given replies to in the past on social media or they were directed to the call centers and that they are the first state institution which gives replies to people on social media in this respect. Ulaş has also expressed that since they use humor on social media but are a state institution at the same time, they use an elite language and they do not decide in the usage of this language through official meetings, it naturally comes forward and that their experiences have steered them to use this language. He has explained that they have decided to use this language in particular in an effort to find an answer to the question "Why would a person follow a municipality?"

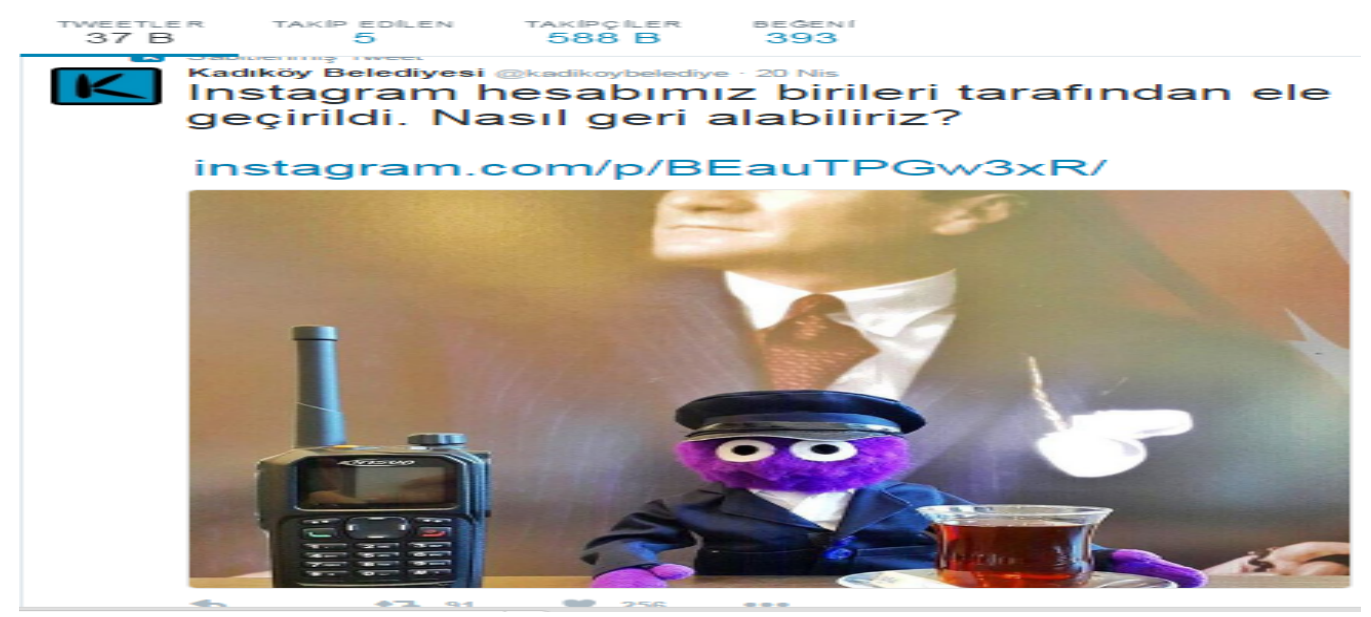

Image 6. Example of create content

In Real Time Marketing, the greatest problem for organizations is that there is an approval process in their content. We at Kadıköy Municipality have by-passed this process for the content we create.

Yılmaz has stated that the social media department of Kadıköy Municipality is now a black box of the municipality; they are in command of data and therefore know which service is being given where and how. Yilmaz continued his words saying that they have identified their own style and principles, have created the Kadıköy Municipality style and that is the reason why they do not need approval mechanisms in their social media content. Yllmaz has expressed that organizations/institution which work with agencies have the most difficulty in this area, because the agencies are not competent about the operations of the organization and that they receive approval and have established trust. He has stated the following about the use of humorous language:

"Besides being a state institution, the humorous language we use has received approval. If you do not know what you are doing, then the humor you use may not be suitable. Therefore, something which comes from an agency may not be accepted within the institution. The joke you make can cause a problem inside, because there might be a problem related to that inside the institution. Agencies may

Submit Date: 01.10.2016, Acceptance Date: 21.12.2016, DOI NO: 10.7456/10701100/009 
not know these processes well. We know very well what a municipality's deficiencies, vulnerabilities, good and bad sides."

We have a unit which supports the problems of our citizens for 24 hours

Yllmaz has stated that they deal actively with the problems of the citizens from 08:00 in the morning until 01:00 at night. He has also stated that the yare active on social media as well and that when an urgent complaint is received, that person is replied to for sure and the complaints received through the wireless operations center are answered for 24 hours. He has stated that they do not answer complaints through the automatic reply method.

\section{All positive and negative replies on social media shared by all employees?}

Yllmaz has explained that the comments on social media are shared not with all employees, but with people who are to solve particular problems.

Are there any services you have developed considering your social media services?

Yllmaz in the interview has stated that the comments on the social media of Kadiköy Municipality are in particular given importance to and that there are services they have developed as a result of these comments. He has explained that urban renewal is being experienced in Kadıköy and that they have brought certain bans on construction activities in this process. He has stated that the ban in question has emerged as a consequence of the complaints made in social media and gave the example of Sunday bans which became effective in Turkey for the first time two years ago. He has explained besides the construction bans that in the recent weeks, they have banned the excavation trucks to be in traffic once again as a result of taking into consideration the complaints in social media. Y1lmaz has stated the following about the residents of Kadıköy area giving them information:

"People are sending photographs and videos from all over Kadıköy; thus, these are very useful for us in reporting. We can show this to the chamber of engineers and the association of businessmen. Complaints are made to our call center and mail addresses, however visual can also come to our social media accounts. People can make unfounded complaints to the call centers as well, but when the issue is visuals on social media, it is more convincing."

Yılmaz has stated that through the Kadıköy on My Mind Project, they have taken the views and projects of the citizens.

\section{There are activities we have succeeded in through social media}

Yllmaz has expressed that they have achieved a tremendous success in 4 years with the Purchasing Owners Project and that the purchasing owners slogan has been approved by many local administrations, artists and brands. Yilmaz has stated that the purchasing owner slogan is given place to in TV series now. Y1lmaz has stated that they have found homes for 650 animals through the project and these animals' vaccinations and care have been taken care of besides having been given for free.

Yllmaz explains the investments and activities they have carried out in line with the feedback they have received from social media as follows:

"For instance, the number of cars, busses and cabs. We are the first in terms of the handicapped cab application. After people have used this service, the demand has increased and the municipality has planned its investments for handicapped cabs accordingly. In this manner, the number of our handicapped cabs has reached 8 in three-four years. Besides these, people are sending us photos of what they see abroad like the handicapped swings."

\section{CONCLUSION}

Today, it is apparent that Real Time Marketing which allows a brand to reach its desired target group by actively participating in the social media platform dialogues used the most by them is an effective marketing method. The most important characteristic which sets Real Time Marketing apart from the others is that it communicates a product or service to the target group just when they need it. The tactic in real time marketing is that there is a race against minutes and even seconds. Another important point is that, it is created through a creative and humorous language in line with the agenda. When the users in social media platforms find the content in question enjoyable and humorous, these are shared

Submit Date: 01.10.2016, Acceptance Date: 21.12.2016, DOI NO: 10.7456/10701100/009

Copyright $\odot$ The Turkish Online Journal of Design, Art and Communication 
immediately and the firms' visibility increase without paying for any advertisement and promotion fee to mass communication tool.

In Real time Marketing Applications, what is important is that it is carried out without harming the reputation of the firm. If not, the firm can receive damage. As for an example, as it has been explained above, a sexy perception has been attempted to be conveyed in the content of KFC's tweet "Warning: Disturbing content! Something hot and spicy is coming" posted on 16 April, 2016 and its visual", however it has lead to KFC to delete the tweet in question and apologize from its users as a result of having a great reaction on social media since it was perceived as extremely obscene by the users. For Real Time marketing to be successful, firstly the content needs to be in line with the agenda of social media and the policy of the firm as well. Content which is created in this manner, fun, humorous, is successful in keeping up with the agenda and suitable for corporate reputation are sure to increase the visibility of the firm. One of the most important points which should be carefully considered is corporate reputation. As it has been explained in the study, although Kadıköy Municipality is a state institution, it has been using both a humorous language and accurately following the current events; and while speedily applying these it has also been able to preserve its reputation. The main function of the municipality of being successful in this is that their social media departments within their body know the municipality very well and the yare very competent in terms of corporate culture. Another reason for their success is instantaneity. The most important reason why Kadiköy Municipality has been successful in this is its creation of content and eliminating of decision mechanisms in their posts.

\section{REFERENCES}

Alabay N. (2010) The Process of Transition from Traditional Marketing to a New One, Süleyman Demirel Üniversitesi İktisadi ve İdari Bilimler Fakültesi Dergisi, Volume 15.

Dennis C. M. (2013) Social Media Defamation and Reputation Management in the Online Age, Journal of Internet Law Volume 17, Number:6

Dişkan P. K. (2016) KFC Paylaştığı Müstehcen Tweetini 1 Saat İçinde Sildi Ama Sosyal Medyanın Gündemi Oldu, http://sosyalmedya.co/kfc-paylastigi-mustehcen-tweetini-1-saat-icinde-sildi-amasosyal-medyanin-gundemi-oldu/, erişim tarihi: 20.4.2016

Cornelissen J. (2004) Corporate Communications: Theory and Practice, Sage Publications, London Er G. (2008) Sanal Ortamda İtibar Yönetimi, İstanbul: Cinius Yay., 1.bs.

Güldaşs E. (2014) Sosyal Medya ve Gerçek Zamanlılık, http://www.emreguldas.com/? s=Real+time+marketing, erişim tarihi: 25.3 .2016

Handley A. and Chapman C. C. (2013) Dijital Çağda İçerik Yönetiminin Kuralları, 2. Baskı, MediaCat, İstanbul

Kadıbeşegil S. (2012) İtibar Yönetimi, İstanbul: MediaCat, 6.bs.

Karaköse T.(2007) Örgütlerde İtibar Yönetimi, Akademik Bakış Uluslararası Hakemli Sosyal Bilimler E-Dergisi, ISSN:1694 - 528X Sayl: 11

Kastrenakes J. (2015) The 11 best April Fools' gags of 2015, http://www.theverge.com/2015/4/1/8327379/april-fools-roundup, erişim tarihi: 28.3.2016

Kiang and et.al. (1999) Marketing on the Internet - who can benefit from an online marketing approach?, 27 (2000) 383-393, Elsevier

Klsosky S.(2011) Manager's Guide to Social Media, New York: McGraw-Hill

Kural S. (2014) Global ve Türk Markalardan Gerçek Zamanll Pazarlama Örnekleri, http://sosyalmedya.co/gercek-zamanli-pazarlama-ornekleri/, erişim tarihi: 28.3.2016

Macy B. and Thompson T. (2011) The Power of Real-Time Social Media Marketing 'How to Attract and Retain Customers and Grow the Bottom Line in the Globally Connected World', The McGrawHill Companies

Markaların Plüton Ile İlgili Gerçek Zamanlı Pazarlama Çabaları (2015) http://fikrimesai.com/markalarin-pluton-ile-ilgili-gercek-zamanli-pazarlama-cabalari/, erişim tarihi: 28.3.2016

Ural E. G. (2012) İtibar Yönetimi Değer Yaratan Bir Halkla İlişkiler Çalışması Olarak İtibar Yönetimi, İstanbul Ticaret Üniversitesi, Cilt: 1, Sayl: 2

Nguyen T. K. (2015) A Study of Real-Time Content Marketing, Turku University of Applied Sciences International, Bachelor of Business Administration, Barchelor's Thesis

Submit Date: 01.10.2016, Acceptance Date: 21.12.2016, DOI NO: 10.7456/10701100/009

Copyright $\odot$ The Turkish Online Journal of Design, Art and Communication 
The Turkish Online Journal of Design, Art and Communication - TOJDAC January 2017 Volume 7 Issue 1

Olenski S. (2015) Real Time Marketing For Social Media: Integrating Large Scale Events,http://www.forbes.com/sites/steveolenski/2015/11/20/real-time-marketing-for-social-mediaintegrating-large-scale-events/\#93c7a736ba8d, erişim tarihi: 22.3.2016

Oliver and et.al (1998)_Real Time Marketing, American Marketing Association Marketing Management, https://www.ama.org/search/pages/archiveresults.aspx? $k=\&$ start1 $=101$, erişim tarihi: 19.3.2016

Reece M. (2010) Real Time Marketing for Business Growth 'How to Use Social Media, Measure Marketing and Create a Culture of Execution', Pearson Education Inc. 